\title{
Family experiences in discovering Autism Spectrum Disorder: implications for family nursing
}

\author{
Vivências familiares na descoberta do Transtorno do Espectro Autista: implicações para a enfermagem familiar
}

Experiencias familiares em el descubrimiento del Transtorno del Espectro Autista: implicaciones para la enfermeira familiar

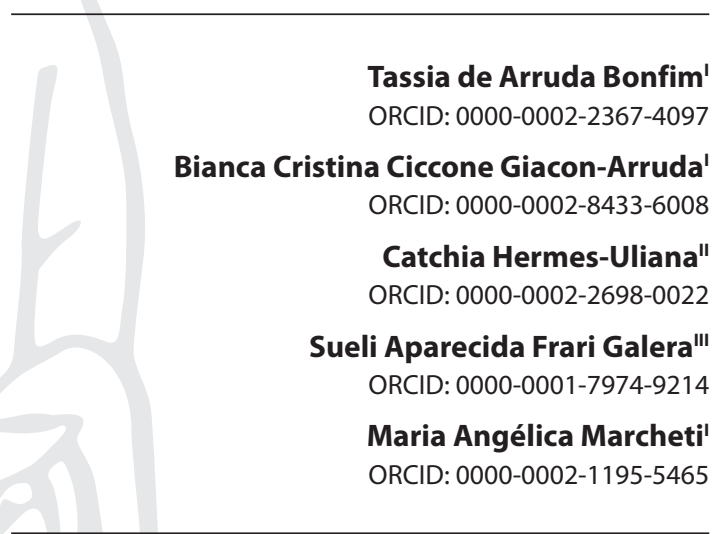

'Universidade Federal de Mato Grosso do Sul. Campo Grande, Mato Grosso do Sul, Brazil.

"Universidade Federal de Mato Grosso do Sul. Três Lagoas, Mato Grosso do Sul, Brazil.

"'Universidade de São Paulo. Ribeirão Preto, São Paulo, Brazil.

How to cite this article:

Bonfim TA, Giacon-Arruda BCC, Hermes-Uliana C, Galera SAF, Marcheti MA. Family experiences in discovering Autism Spectrum Disorder: implications for family nursing.

Rev Bras Enferm. 2020;73(Suppl 6):e20190489. doi: http://dx.doi.org/10.1590/0034-7167-2019-0489

\section{Corresponding author: \\ Tassia de Arruda Bonfim \\ E-mail: tasbonfim0@gmail.com}

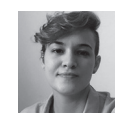

EDITOR IN CHIEF: Antonio José de Almeida Filho ASSOCIATE EDITOR: Marcos Brandão

Submission: 06-25-2019

Approval: $04-23-2020$

\section{ABSTRACT}

Objectives: to describe the family's experience in the process of discovering the diagnosis and initiation of treatment of children with Autism Spectrum Disorder. Methods: this qualitative and descriptive study interviewed nine relatives of eight children on autism spectrum. They were inserted in health services, public education, and Association of Parents and Friends of The Exceptional of cities in the countryside of the Center-West. Data were collected through open interviews from July to September 2017. Data was submitted to thematic analysis. Results: at the beginning, the family was difficult to perceive the first atypical signs presented by the children. Families experience situations of vulnerability, since support networks are insufficient. The school played a significant role in recognizing unexpected behaviors. Final Considerations: support, offered by nurses, health professionals, school and social support devices, is important to family and children in this trajectory.

Descriptor: Family; Diagnosis; Autism Spectrum Disorder; Child; Family Nursing.

\section{RESUMO}

Objetivos: descrever a vivência da família no processo de descoberta do diagnóstico e início do tratamento de crianças com Transtorno do Espectro Autista. Métodos: estudo qualitativo, descritivo, que entrevistou nove familiares de oito crianças no espectro do autismo, inseridos nos serviços de saúde, educação pública e Associação de Pais e Amigos dos Excepcionais de municípios do interior da região centro-oeste. A coleta de dados foi realizada por entrevistas abertas, nos meses de julho a setembro de 2017. Os dados foram submetidos à análise temática. Resultados: no início, houve dificuldade da família na percepção dos primeiros sinais atípicos apresentados pelas crianças. As famílias vivenciam situações de vulnerabilidade, visto que redes de apoio são insuficientes. A escola teve papel significativo no reconhecimento de comportamentos inesperados. Considerações Finais: ressalta-se a importância do suporte à família e crianças nessa trajetória oferecido por enfermeiros, profissionais de saúde, escola e dispositivos de suporte social.

Descritores: Família; Diagnóstico; Transtorno do Espectro Autista; Criança; Enfermagem Familiar.

\section{RESUMEN}

Objetivos: describir la experiencia de la familia en el proceso de descubrir el diagnóstico y comenzar el tratamiento para niños con Trastorno del Espectro Autista. Métodos: estudio cualitativo, descriptivo, que entrevistó a nueve miembros de la familia de ocho niños en el espectro del autismo, insertado en los servicios de salud, educación pública y Asociación de Padres y Amigos de Personas con Discapacidad de ciudades en el interior de la región centro-oeste. La recolección de datos se realizó a través de entrevistas abiertas, de julio a septiembre de 2017. Los datos se sometieron a análisis temático. Resultados: al principio, la familia tuvo dificultades para percibir los primeros signos atípicos presentados por los niños. Las familias experimentan situaciones de vulnerabilidad, ya que las redes de apoyo son insuficientes. La escuela jugó un papel importante en el reconocimiento de comportamientos inesperados. Consideraciones Finales: se enfatiza la importancia del apoyo para la familia y los niños en esta trayectoria ofrecida por enfermeras, profesionales de la salud, dispositivos escolares y de apoyo social.

Descriptores: Familia; Diagnóstico; Trastornos del Espectro Autista; Niño; Enfermería de la Familia. 


\section{INTRODUCTION}

Autism Spectrum Disorder (ASD) is a neurodevelopmental disorder of biological origin and environmental influences. Its manifestations are related to deficits in verbal and nonverbal communication, in the ability to relate, presence of stereotyped patterns, particular interest in specific activities and patterns of repetitive behaviors ${ }^{(1)}$.

A study conducted in the United States shows the estimated prevalence of one in 59 children aged eight years, more frequent in boys, in the proportion of four boys to one girl ${ }^{(2)}$. In Brazil, there are no official data on the prevalence of ASD. A single study was conducted in a city in the countryside of São Paulo, which presented an incidence of one to 330 live births. However, there is variability of findings and methodological aspects that suggest that the results should not be generalized to other Brazilian cities ${ }^{(3)}$.

In this context of studies on ASD, the literature demonstrates that illness causes several changes and changes in the life of children and their family. These changes impact family life and are described as difficult to face. They involve changes in family dynamics and relationships, social interaction with friends, burden of care, marital conflicts and social isolation ${ }^{(4-5)}$. This context requires a process of adaptation and changes in the routine and personal life of parents and children ${ }^{(6)}$.

Concerning discovery and diagnosis, the family has difficulty understanding the atypical behaviors presented by the children, early recognition of illness, accessing health care services, accepting the diagnosis. Also, it is being permeated by the constant search of doctors for other opinions and by feelings such as frustration and mourning, due to the loss of the ideal child and rearrangement of the family as a whole ${ }^{(7-8)}$.

For this reason, children diagnosed with ASD require specialized care and early stimulation therapies. The family, due to the impact of illness and changes, also need support and assistance, mainly to learn how to deal with this new reality and to rearrange themselves in the face of new demands and changes. When the family and the child have support of specialized services, there is a significant improvement in their well-being and in reduction of stress ${ }^{(9)}$.

In the context of public policies, the person with ASD is supported by Política Nacional de Proteção dos Direitos da Pessoa com TEA (Brazilian National Policy for the Protection of the Rights of Persons with ASD) ${ }^{(10)}$ and by Política Nacional de Saúde da Pessoa com Deficiência (Brazilian National Health Policy of Persons with Disabilities). This last policy is focused on the inclusion of people with disabilities in the entire network of services of Sistema Único de Saúde (Brazilian Unified Health System, SUS). It has as guidelines promotion of the quality of life of this population, comprehensive assistance, prevention of deficiencies, increase and consolidation of existing means of information, as well as organization, operation of services, and preparation of human resources ${ }^{(11)}$.

Although the literature presents evidence of the benefits in caring for families and public policies also propose this view, their inclusion has not been routine in health services ${ }^{(9)}$. Care is still based on a child-centered model and disability and condition, mainly by specialist health professionals. The care provided to families is focused, especially, on guidance on the disorder and the new demands of child care, not receiving assistance in their needs as a family unit ${ }^{(5-12)}$.

This fragility in the care of children with ASD and their families goes the opposite way with the implementation of public policies, mainly caused by the unpreparedness of health professionals. This happens due to little knowledge on how to care for children and families, feeling of insecurity in providing care, difficulty of organizing and integrating the health care network, and stigma related to mental disorders ${ }^{(8-14)}$.

Family nursing recognizes the impact that illness causes on the family and assists it in their demands, needs and suffering, helping them to find coping strategies, organization and adaptation to this new reality. In this sense, nursing professionals are fundamental in caring for this population ${ }^{(12)}$. Thus, studies on the experience of these families can contribute to a better understanding of the process of discovery of diagnosis and initiation of treatment. With this in mind, from the care and intervention proposals in nursing, better assistance and promotion of a more effective implementation of public policies aimed at this population will be provided.

\section{OBJECTIVES}

To describe the family's experience in the process of discovering the diagnosis and initiation of treatment of children with ASD.

\section{METHODS}

\section{Ethical aspects}

The Research Ethics Committee Involving Human Beings of the Universidade Federal do Mato Grosso do Sul approved the study, under Opinion 2148,820, of 2017, according to CNS (Conselho Nacional de Saúde - Brazilian National Health Council) Resolution 466/12. All participants were informed about the objective of the study, their rights and signed the Informed Consent Form.

\section{Theoretical-methodological framework}

The theoretical framework Symbolic Interactionism was used, which is based on the relationships and interactions of individuals with the environment and with their peers. It defines family as a social group that develops concepts and identity itself through interaction with each other and with individuals in the social sphere in which they live. The family attributes meanings to these experiences, which result from their interactions ${ }^{(15)}$.

\section{Type of study}

This is a qualitative and descriptive study. The qualitative method seeks to understand the intrinsic reality that individuals are inserted and what meaning they give to that experience. The researcher studies the universe of individuals considering their environment, beliefs, values, relationships, and behaviors in the face of life situations ${ }^{(16)}$. The Consolidated Criteria for Reporting Qualitative Research (COREQ) was used to ensure better validity of methodological aspects ${ }^{(17)}$. 


\section{Study setting}

The study was carried out in five cities in the countryside of northern State of Mato Grosso do Sul. Health services, education, and Associações de Pais e Amigos dos Excepcionais (Association of Parents and Friends of The Exceptional - APAE) were included.

\section{Study participants}

To select the study participants, we used the concept of family in which defines it as a group of individuals connected to each other by affective bonds, who recognize themselves as family and that has implications in the life of the other ${ }^{(12)}$.

Families of children with ASD participated in the study, which were selected by convenience sampling. That is, we contacted health and education services (Basic Health Units and Municipal Departments of Education), and APAE to request the relationship of children with diagnosis or diagnostic hypothesis of ASD and their families.

A total of 13 children and their families were indicated by the services. A first contact was made by telephone call, with all the families indicated, to invite to participate in the study. Three families refused for the option of not exposing the child. After this first contact, an interview was scheduled at the family residence and all members were invited to participate. Two families could not be interviewed due to setbacks on the part of the participating family member. Thus, of the 13 families of children indicated and invited, eight were included in the study and a total of nine family members participated.

The inclusion and exclusion criteria of participants were: being a relative of a child diagnosed with a diagnosis or diagnostic hypothesis of ASD for at least one year at the time of the interview; being over 18 years of age, being involved in direct care of the child and having cognitive ability to participate in the interview.

\section{Data collection and organization}

A meeting was held with each participating family, in their own residence, except for a family in which the meeting took place in a place indicated by them in a private environment. The study was conducted by two main researchers, one nurse and another PhD in psychiatric nursing and family nursing, and with experience in qualitative studies. Data collection was performed by the principal nurse, previously trained. None of the researchers had contact or previous knowledge about the families.

With each family, an open interview was conducted through the guiding question: how is the experience of being a family member of a child with ASD? It was followed by auxiliary questions in order to guide and deepen information pertinent to the objective of the study. A socio-demographic questionnaire elaborated by the researchers was applied. The questions were organized based on a literature review of studies on the subject, and the expertise on the theme of one of the main researchers.

Data collection took place between July and September 2017, the interviews were on average 60 minutes long and were recorded on audio media. As it was possible to identify and invite all families that met the inclusion and exclusion criteria, and the sample was for convenience, data saturation was based on the exhaustive analysis of all interviews conducted.

All interviews were fully transcribed by the main nurse researcher and all information that could identify the families was withdrawn. Each family received a code prepared with the letter I (interview) and a number referring to the order that the interviews were conducted (I1 to I8).

\section{Data analysis}

Data analysis was based on thematic analysis, proposed by Minayo ${ }^{(16)}$. Mainly used in research in the field of social sciences, thematic analysis as a technique of data interpretation comprises a three-step process, which involves pre-analysis, exploration of material, treatment and interpretation of results ${ }^{(11)}$.

Only one family was present on the day of presentation of the study results and can validate them. The others were not possible because they lived in different cities. However, data analysis was performed by the two main researchers, independently, through a table elaborated by them, which included the statements of the study subjects, analysis, interpretation and the implications and reflections of the reports.

The key points and themes were identified through the reflections and interpretations presented in the tables. After independent analysis, the researchers carried out an in-depth reading of the reports and their analysis in sets, which made it possible to establish the themes in a more precise way. It was validated by two other researchers, a doctor in psychiatric nursing, another in pediatric nursing and both in family nursing.

Analysis of the reports was carried out in the light of SI and in its perspective that the family means its experience through the social interactions that it establishes. They were grouped and organized chronologically, presented in two categories:"Perception of the first signs and trajectory in the search for answers" and "Initial impact of diagnosis at the beginning of treatment and its implications".

\section{RESULTS}

Nine relatives from eight families participated in the study, and in one interview the mother and father dyad participated, and the others only mothers participated. All the families had their mother as their primary caregiver. Regarding marital status, three were married, three single, one divorced and one as a stable union. The age of the children ranged from three to nine years.

Regarding the diagnosis of children with ASD, four already had it, and four had a diagnostic hypothesis. However, all were undergoing treatment and follow-up for ASD in health services. Of the eight children, one was diagnosed confirmed and started treatment before the age of three.

\section{Perception of the first signs and trajectory in the search for answers}

Family members reported that they began to notice some changes in the development of their children and behaviors different from those expected for age, such as difficulty in interacting in the school environment, isolation of activities in groups, setback/ 
loss in language development and social skills. The mothers had difficulty in identifying the first signs of the disorder, and meant such behaviors or alterations as personal characteristics of the child or of their own age and that they could pass.

The school was reported by family members as the main institution that perceived behaviors and aspects of development that were not appropriate with the child's age, and communicated/ talked to parents about it.

She used to sing until she was three [...] after three years and a little, she was blocking herself [...] she was not much to be with other children, [...] she started at the nursery with two years and the teachers said, "Mother, she doesn't have other children to play with, she doesn't speak". But at home she used to talk. She used to sing it all, that's why I don't go after it. (I8)

The principal came to speak to me kindly, and I had already noticed that he was a little different. I had already noticed, but it is something that you watch, the mother watches, she keeps a little quiet, thinking it may be a phase thing. (15)

Some families sought health services and started treatment for signs and symptoms of neurological diseases, associated with previous experiences in the child's development, such as seizures and high fever already in the first year of life.

Since he was 10 months old, he had [first seizure]. [...] first, we started treating him with epilepsy, he is epileptic. After some time, we started to notice some characteristics that are of the autistic spectrum. (15)

Because, when he was about four months old, he was already very early. I was already sitting up, until I had a fever that was not diagnosed until today. A neurological fever that affected all his movements, and he regressed. (16)

From the school approach, the families were referred and instructed to seek health institutions or educational institutions specialized in children with developmental alteration or deficit, for an evaluation of the child.

Then, it [school] said that she had already contacted the municipality's education department and the department had already called APAE in case I was interested. I didn't have to take him there to do a screening with the specialists. (I5)

The narratives reported that the obstacles faced affected the family's routine in this phase of child evaluation, mainly because they needed to go to another city to have access to specialist professionals. Reconciling a fixed job was described as difficult at the time.

I already had to leave the service once. The other one I was on, I had to travel. Right now, I have to travel directly to the capital [...] these trips are usually on Saturday, I try to schedule on Saturday, that I don't work, I work Saturday every Saturday or no. Now, I had to leave three days of service last week, Monday, Tuesday and Wednesday, it is not cool [...] you go to five types of doctors or more, you arrive, you have to run after school paperwork, everything. (14)

Another reported difficulty was the lack of a support network, both professional, social and family. The mothers, in the role of primary caregivers, reported the absence of support offered by other family members in this process. Some families reported the lack of support from the child's father and social support and health care devices and that care is focused on the care of the child and not the family.

At first, it was a little like, "Hey, I'm alone, help me? You are my husband, you are the father, so help me search". I didn't have this support at the beginning or even now. (17)

When I found out, the problem is that we don't have support, we don't have a nucleus that serves the parents, all care and laws are geared towards the child [...] so, the family doesn't have support. (I1)

The family also suffers an impact on social interactions and relationships. They are a consequence of the family's difficulties in managing the behaviors of children and other people in understanding the behaviors of children with ASD not as a possible illness, but as inadequate and not handled correctly by parents.

Look, before diagnosis, it was terrible, because we didn't go out, we didn't go to anyone's house, until we understood that what happened to him was a super antisocial situation [...] going out to go to a child's party, that they always invited us, I would go home crazy, he wouldn't stop. (I2)

Everyone was stressed about him. My sister was even too stressed because she didn't know and thought it was bad behavior. Untill reached out to her and showed her, then she took a step back, you know? If not, my God, he drove everyone crazy. (17)

\section{Initial impact of diagnosis at the beginning of treatment and its implications}

After the trajectory described between the perception of the signs and the search for help with explanations, the family receives a diagnostic hypothesis and starts the process of searching for information about the diagnosis received. The participants' narratives described that experiencing the possible diagnosis of ASD, by medical professionals, was a difficult experience, permeated by feelings of shock, sadness, intense crying and difficulty to accept. In the reports, mothers report that they did not know the disorder and were afraid of the unknown.

As if the world had fallen. So, when I left the doctor's office and he said, "this is a syndrome", I left desolate there, even wanting to cry. I didn't go out crying, because I still had the other [son] who was with me. I had to be very strong and give him strength too, take strength from I don't know where. (16)

These feelings, according to the reports, were generated mainly by the unknown, i.e. because they did not know what the future of the child would look like.

It wasn't easy and it isn't [I cry], because sometimes I cry, because I think about her future. How will it be? Because she totally depends on me. (18)

However, receiving the diagnosis was also described as a relief, because in the perspectives of the families, not knowing what the child had also generated a feeling of despair. 
I think I was already kind of prepared, because I wanted someone to say what he had. He was going to one doctor and another, and they would just ask for exams, and I didn't know what it was. They never said anything. That is more desperate than when a doctor says, "look, he has this, now let's treat this", you going after what he has is much more difficult. (I7)

Thus, after the initial impact, the diagnostic hypothesis generated the possibility for the family to understand the reason for the atypical behaviors presented by the children. So, with that, they had a point to start looking for more information about the disorder, its treatment and the rights of their children.

For me, all the children I saw, who lived with me as a child, had no such problem. So, for me, when I saw it, it was a shock, but then I started talking, talking and I started to understand. (I3)

I went to study about the subject, I went to look for information. First, it was a shock, I cried, I stayed like that, but then I stopped and concentrated and went to get information about it. And then I discovered these characteristics. (15)

Upon understanding the child's diagnosis, the families began the search for adequate and specialized health care, with the hope of taking care of their children and learning to manage their behavior. Some schools provided an auxiliary teacher to follow the child up in the classroom and drug treatment was started.

Because, now, he has been diagnosed, he has started taking the right medication, he is already doing it, he even has a teacher. I forgot to mention that there is even an auxiliary teacher turned only to him inside the classroom, that we also managed [...] the neuropediatrician prescribed that he had a follow-up inside the classroom and then we went after it and succeeded, we went to the education department and we did it. (16)

With the beginning of treatment, some families referred to the implications of having a child with ASD in the family environment and the family's perception of the new reality. It was observed that, with the treatment started, there is an evolution and improvement of the child's behaviors and better social interaction.

We went to a friend's farm and she went into the bush, disappeared, every time she had to be aware [...] this changed with the $A B A$ method, which is behavioral and also changed with the medication that she did to focus. She had no focus, she went out, she moved here, she dropped there, she left here, she walked. (I1)

There was a good improvement, the psychologist has been fundamental for this [...] with the regular teacher, with this tutoring and with the psychologist [...] with treatment, everything is possible, isn't it? We found out that the only problem was that we diagnosed what it was about and then didn't know how to act, but after that. (16)

However, even after starting treatment, some families reported difficulties in dealing with the new reality and implications of the diagnosis of ASD, such as adapting to the child's condition, limitations, demands and specialized care and treatment.

His father doesn't accept it, so he deals on the basis of the aggression [...] he is rude to him, you know, anything is "Oh, I'm going to spank you!" "Ah, I'm going to hit you because you do it because you want to" [...] and not that you are treated that way, because how people treat you, like even his father here, affects him even more. (14)

Now, it's normal for me, I can accept it. I didn't want to accept him studying there at APAE [...] because, for me, there was only a place for disabled children, who can't walk, eat alone, who can't do anything, but he does all of this. For me, he couldn't go there. (I3)

In addition to family members, some people from the social environment of the families also disbelieved that the child had ASD, because they did not have apparent physical alterations. They believed that the behaviors manifested by the child were typical of age and child development such as stubbornness, tantrum, whimsy, among others.

People are speculating and I say: "She is autistic!" Then people say "Wow! She is? Really? If you didn't speak, I wouldn't know" [...] because it's not in the face, written. Those who see it are not even able to perceive that the girl is. (18)

It is logical that there are those relatives who think the disorder is mental disability, there are those relatives who think it is bad behavior, which is lack. They do not believe because she is cute. (I1)

The implications generated in the family in the face of reports about difficulties in accepting family and friends were described as difficult moments. However, receiving the diagnosis and initiating interventional measures in child care was reported as an important factor that helped in family and social life. Not only drug treatment when indicated, but also psychosocial and psychoeducational treatments.

The whole family structure, the whole social life with the treatment has improved, hasn't it [question to the father]? Two hundred percent. Social life was very complicated, we couldn't go and we ended up going out or I or he came back very stressed, because I had to be on account of one. (I1)

So, with medication and treatment, he calmed down, so today, for him to listen, I tell him that he is nervous there, he stops and starts to breathe, because he knows that he has to calm down, today he knows that he takes medicine. (I2)

\section{DISCUSSION}

This research revealed that the experience of family members in the process of diagnosis and beginning of treatment is divided into two stages. The first refers to the period prior to the diagnosis, when it was perceived, by the parents or by the school, that the child's behavior was not appropriate for their age and a search for explanations began. The second, after diagnosis and start of treatment, when there was relief from the previous period and a rearrangement of the family system in the new context. In the light of SI, it can be identified that, throughout this process, the family, through its experiences, beliefs and interactions, develops meaning to what they experience, which influence their perception of the new reality and their behaviors and actions.

When the first signs appear and the family begins to notice the child's first behavioral changes, there is a difficulty in recognizing 
a possible illness. The meaning that such behaviors or changes may be personal characteristics of the child or his own age and that he would pass. This meaning can be linked to the feeling of fear that permeates this initial phase and family relationships, especially related to the idealized future built by the family for the child ${ }^{(5-18)}$.

Therefore, when parents notice that the child's development does not occur in the expected way, they begin to pay attention to behaviors. In these moments the mother, who is responsible for the main care of the child, is the person who initially perceives the atypical development in the child ${ }^{(19)}$.

The school was an important device in identifying the first signs of illness. It assisted in guiding families in seeking help in some health service or special education for an initial assessment. Other studies also point out the important role of teachers and the school in identifying children with possible manifestations of ASD. It is in the school environment that the child is stimulated in several aspects, such as forms of verbal and non-verbal communication, and social interaction. These functions may be impaired when the main manifestations of ASD start ${ }^{(20-21)}$.

From the identification of behaviors that signal for ASD and help from educational institutions, family members experience new questions about the explanations for the reality experienced with their child. With that in mind, they started the search for a specialized evaluation in specific health or educational services. In this way, recognizing the early signs of ASD enables the family to recognize and seek help in specialized services. They can provide diagnosis and initiation of necessary interventions early in the development of the disorder, providing a better prognosis for the child(22).

This early recognition of changes in development should also be carried out in the follow-up of this child in primary health care services such as routine consultations and vaccination moments. For this, it is necessary that the team is trained to recognize the first signs of ASD and carry out appropriate referral and follow-up for the child and family.

However, a study conducted in the United Kingdom investigated the knowledge of health professionals about ASD. The results of the study indicated that professionals have difficulties in recognizing the main developmental delays and, according to the participating parents, they did not have adequate training to deal with the disorder and insufficient knowledge ${ }^{(23)}$. This context is also perceived in Brazil about nursing, and, therefore, investing in training and strengthening of public policies are priority needs in our context ${ }^{(14)}$.

A challenge for the population in this study was the absence of specialized services in the care of these children and their families in the municipality of residence. The children were referred to APAE, mainly because it was an available service that had a multidisciplinary team. However, because the assistance received in these institutions is not directed to the specificities of ASD, the families went to the State capital to obtain assistance from specialists to obtain the diagnosis.

This reality reflects a weakness in the implementation of public policies aimed at people with disabilities ${ }^{(11)}$. It directly interferes with the supply of trained professionals and comprehensive and adequate assistance to the individual and his family. The itinerary between one city and another, due to this fragility, causes the delay in diagnosis, the experience of several obstacles and anxiety in the face of the difficulties encountered ${ }^{(19)}$. These issues imply suffering for the family and the child's prognosis. It is known that identifying the disorder and initiating interventional measures early, such as behavioral therapies or sensory integration approaches ${ }^{(24)}$, allow a better prognosis related to development, especially when based on the needs of each child, because the manifestations of ASD are presented different in each ${ }^{(22)}$.

When the diagnosis or suspicion was confirmed by the professionals, the family described this moment as difficult to accept and frustrate, permeated with feelings. Although experiencing the impact of the diagnosis is difficult at first, having the diagnosis helped to understand the disorder, helped in the search for treatment and in the management of the child's behaviors. The experience of diagnosing a chronic health condition in a child causes an emotional impact due to the diagnosis and disappointment in the child's idealized life. This suffering is experienced by each family member differently and at different times ${ }^{(25)}$, especially when the family does not have a support network to support their needs(26).

The implications of non-acceptance and difficulty encountered in the therapeutic path affect the child's development and, consequently, affect the family's quality of life. These data corroborate those described in the literature that identified that the scarcity of services available to assist children and families in health and social support was a factor that increased stress and decreased the quality of life of family members in charge of care ${ }^{(26)}$.

In this study, families and friends reported finding difficulties in accepting behavior and diagnosis, which caused social isolation from the family. Isolation from social life may occur due to the population's lack of understanding of the disorder, which is often manifested through discriminatory attitudes of people ${ }^{(13)}$. This stigma experienced may be related to lack of knowledge, judgment, rejection and lack of support. And that these situations happen in school, community, with families and friends. The work of sensitization and awareness should also be directed to these places ${ }^{(13)}$.

The family also has needs amid the frustration experienced by the diagnosis, such as negative emotional impact, needs in family relationships and social rights ${ }^{(5)}$. The inability of professionals to communicate the diagnosis is also considered a family need, as well as clear information about the disorder ${ }^{(8)}$.

Thus, the paths along the search for diagnosis have an impact on the child and the family, which are under a new perspective. With this, the family changes its functioning, which brings changes and requires rearrangement and adaptation to the new reality ${ }^{(4,19)}$. Rearranging the family due to illness is multifactorial and depends on the interactions between individuals and the meaning attributed ${ }^{(15)}$. Thus, rearranging families of children with ASD depends on their previous experiences, on the beliefs of their members and on the meaning attributed by each and the group ${ }^{(12)}$.

The results showed that family experiences are based on the care offered to the child. They refer to the absence of family, social and institutional support and assistance focused on the family as a care unit and its needs. This absence can be justified 
because the assistance is based, predominantly, on the biomedical model of care. In this way, the family is unassisted. The health professional must welcome, listen to families in their needs, use strategies that support family members. Family Centered Care (FCC) and family nursing intervention models have shown positive results in the care of families of children in chronic health and disability situations ${ }^{(25)}$.

Family nursing interventions, based on the FCC model, recognize it as a care unit, and not just the sum of its parts ${ }^{(25)}$. In this perspective, the illness of a member influences the whole family, in its different dimensions, structural, functioning and development, involving their beliefs, knowledge, emotions, roles, tasks, and others ${ }^{(12)}$.

In this way, it is possible to understand the family through their own lenses, recognizing their reality, needs, demands and suffering. Helping them to understand the suffering and changes resulting from the illness, their strengths and potential, and to develop coping strategies and rearrange the family dynamics provides a reduction in suffering and a better quality of life ${ }^{(12)}$.

A study that investigated the philosophy of FCC in ASD showed positive experiences of family members and health professionals regarding its implementation in the care of these families. Exploring the implementation of FCC in a Brazilian service that serves families of children with autism may be a strategy that improves the assistance received ${ }^{(27)}$. For this reason, understanding the impact and experience of families of children with ASD is necessary not only to understand each member and their role within the family context, but also the dynamics of the family in the experience of illness.

\section{Study limitations}

It is identified as a limitation that families live in different cities, which made it difficult for the researcher to return for data validation. To minimize this limitation, data analysis was performed independently by two researchers, validated by two other researchers who are specialists in the subject. Another limitation is that half of the families had only a suspected ASD diagnosis. This fragility is justified by the waiting time of some families for specialized services until the confirmation report by a specialist.

\section{Contributions to nursing and health}

Care strategies can be directed to families, based on family nursing interventions that recognize the family as a care unit and assist them in order to promote their empowerment for the necessary confrontations. They also contribute to the daily interaction between family and child, reducing stress and suffering and promoting an increase in the quality of life of those involved.

In primary care, nursing has been monitoring this population since prenatal care, becoming an important professional in the early recognition of developmental changes, conducting more appropriate health referrals and follow-ups, and in the articulation of these networks. Family nursing interventions can contribute to better care for this population in their different life cycles, providing better quality of life, more adapted coping and lower levels of suffering for children and families.

\section{FINAL CONSIDERATIONS}

Families of children with ASD face challenges in the discovery of diagnosis and initiation of treatment, which requires transformations in their perceptions in the face of the new experience. Families find it difficult to have access to specialized services and diagnosis.

This study demonstrates the fragility in the implementation and implementation of public policies regarding the care of people with ASD and the line of care for people with ASD and their families in the psychosocial care network of SUS. It is believed that the implementation of these public policies can contribute to a better organization of the health care network of people with disabilities and their integration of primary care. In this sense, nurses need to appropriate the knowledge of this care network, and their role in the team and in different health services, in order to promote an integrated, articulated and effective network in the different points of care, and to direct care actions that address the needs and demands of both the child and the family.

School and teachers are important actors, because they helped in the initial identification of behavioral alterations, which motivated families in the search for help, enabling early diagnosis, as well as positive implications on the prognosis of the disorder and on the lives of children and their families. Articulation between educational institutions, health, as well as with other devices of assistance to this population is important and necessary.

\section{FUNDING}

This study was financed in part by the Fundação Universidade Federal de Mato Grosso do Sul - UFMS/MEC - Brazil, and the Coordenação de Aperfeiçoamento de Pessoal de Nível Superior - Brasil (CAPES) - Finance Code 001.

\section{REFERENCES}

1. Lord C, Elsabbagh M, Baird G, Veenstra-Vanderweele J. Autism spectrum disorder. Lancet. 2018;392:508-20. doi: 10.1016/ S0140-6736(18)31129-2

2. Baio J, Wiggins L, Christensen DL, Maenner MJ, Daniels J, Warren Z et al. Prevalence of autism spectrum disorder among children aged 8 years - Autism and developmental disabilities monitoring networks, 11 sites, United States, 2014. MMWR Surveill Summ 2018;67(No.SS-6):123. doi: $10.15585 / \mathrm{mmw}$.ss6706a1

3. Paula CS, Ribeiro SH, Fombonne E, Mercadante MT. Prevalence of pervasive developmental disorder in Brazil: a pilot study. J Autism Dev Disord. 2011;41(7):1738-42. doi: 10.1007/s10803-011-1200-6 
4. Pinto RNM, Torquato IMB, Collet N, Reichert APS, Souza Neto VL, Saraiva AM. Autismo infantil: impacto do diagnóstico e repercussões nas relações familiares. Rev Gaúcha Enferm. 2016;37(3):1-9. 10.1590/1983-1447.2016.03.61572

5. Mapelli LD, Barbieri MC, Castro GVDZB, Bonelli MA, Wernet M, Dupas G. Criança com transtorno do espectro autista: cuidado na perspectiva familiar. Esc Anna Nery. 2018;22(4):1-9. doi: 10.1590/2177-9465-ean-2018-0116

6. Hartley SL, Schultz HM. Support needs of fathers and mothers of children and adolescents with autism spectrum disorder. J Autism Dev Disord. 2015;45(6):1636-1648. doi: 10.1007/s10803-014-2318-0

7. De Pape AM, Lindsay S. Parent's experiences of caring for a child with autism spectrum disorder. Qualit Health Res. 2015;25(4):569-83. doi: $10.1177 / 1049732314552455$

8. Morris R, Greenblatt A, Saini M. Healthcare providers' experiences with autism: a scoping review. J Autism Dev Disord. 2019;49(6):2374-2388. doi: 10.1007/s10803-019-03912-6

9. Nascimento YCML, Castro CSC, Lima JLR, Albuquerque MCS, Bezerra DG. Transtornos do espectro autista: detecção precoce pelo enfermeiro na Estratégia Saúde da Família. Rev Baiana Enferm. 2018;32:e25425. doi: 10.18471/rbe.v32.25425

10. Ministério da Saúde (BR). Lei no 12.764, de 27 de dezembro de 2012. Institui a Política Nacional de Proteção dos Direitos da Pessoa com Transtorno do Espectro Autista [Internet]. Diário Oficial da União: República Federativa do Brasil. 2012 [cited 2019 Jan 20];28 de dezembro; Seção 1. Available from: http://www.planalto.gov.br/ccivil_03/_Ato2011-2014/2012/Lei/L12764.htm

11. Ministério da Saúde (BR). Gabinete do Ministro. Portaria GM/MS no 1060, de 05 de junho de 2002. Institui a Política Nacional de Saúde da Pessoa Portadora de Deficiência [Internet]. Diário Oficial da União: República Federativa do Brasil. 2002 [cited 2019 Jan 20];05 de junho. Available from: http://bvsms.saude.gov.br/bvs/saudelegis/gm/2002/anexo/anexo_prt1060_05_06_2002.pdf

12. Wright LM, Leahey M. Enfermeiras e Famílias: guia para avaliação e Intervenção na Família. Roca. 5ed; 2012. 392p.

13. Broady TR, Stoyles GJ, Morse CM. Understanding carers' lived experience of stigma: the voice of families with a child on the autism spectrum. Health Soc Care Community. 2017;25(1):224-33. doi: 10.1111/hsc.12297

14. Sena RCF, Reinalde EM, Santos Silva GW, Sobreira MVS. Prática e conhecimento dos enfermeiros sobre autismo infantil. Rev Pesqui Cuid Fundam. 2015;7(3):2707-16. doi: 10.9789/2175-5361.2015.v7i3.2707-271

15. Blumer, H. Symbolic interacionism: perspective and method. Berkeley: University of California, 1969.

16. Minayo, MCS. O desafio do conhecimento: pesquisa qualitativa em saúde. 14a ed. São Paulo: Hucitec; 2014. 408 p.

17. Tong A, Sainsbury P, Craig J. Consolidated Criteria for reporting qualitative research (COREQ):a 32-item checklist for interviews and focus groups. Int J Qual Health Care. 2007;19(6):349-57. doi: 10.1093/intqhc/mzm042

18. Nicholas DB, Zwaigenbaum L, Ing S, MacCulloch R, Roberts W, McKeever P, et al. "Live it to understand it": the experiences of mothers of children with autism spectrum disorder. Qual Health Res. 2016;26(7)921-934. doi: 10.1177/1049732315616622

19. Ebert M, Lorenzini E, Silva EF. Mães de crianças com transtorno autístico: percepções e trajetórias. Rev Gaúcha Enferm. 2015;36(1):49-55. doi: 10.1590/1983- 1447.2015.01.43623

20. Favoretto NC, Lamônica DAC. Conhecimento e necessidades dos professores em relação aos transtornos do espectro autístico. Rev Bras Ed Esp. 2014;20(1):103-16. doi: 10.1590/S1413-65382014000100008.

21. Minatel MM, Matsukura TS. Familiares de crianças e adolescentes com autismo: percepções do contexto escolar. Rev Ed Esp. 2015; 28(52):429-42. doi: 10.5902/1984686X14708

22. Elder JH, Kreider CM, Brasher SN, Ansell M. Clinical impact of early diagnosis of autism on the prognosis and parent-child relationships. Psychol Res Behav Manag. 2017;10:283-92. doi: 10.2147/PRBM.S117499

23. Dillenburguer K, McKerr L, Jordan JA, Keenan M. Staff training in autism: the one-eyed woman. Int J Environ Res Public Health. 2016;13(7):217. doi: 10.3390/ijerph13070716

24. Ministério da Saúde (BR). Secretaria de Atenção à Saúde. Departamento de Atenção Especializada e Temática. Linha de cuidado para a atenção às pessoas com transtornos do espectro do autismo e suas famílias na Rede de Atenção Psicossocial do Sistema Único de Saúde. Brasília: Ministério da Saúde, 2015. 156 p.

25. Marcheti MA, Mandetta MA. Criança e adolescente com deficiência: programa de intervenção de enfermagem com família. Goiânia: AB; 2016. $120 \mathrm{p}$.

26. Vohra R, Madhavan S, Sambamoorthi U, St Peter C. Access to services, quality of care, and family impact for children with autism, other developmental disabilities, and other mental health conditions. Autism Open Access. 2014;18(7):815-826. doi: 10.1177/1362361313512902

27. Hodgetts S, Nicholas D, Zwaigenbaum L, McConnel D. Parents' and professionals' perceptions of family-centered care for children with autism spectrum disorder across service sectors. Soc Sci Med. 2013;96:138-146. doi: 10.1016/j.socscimed.2013.07.012 